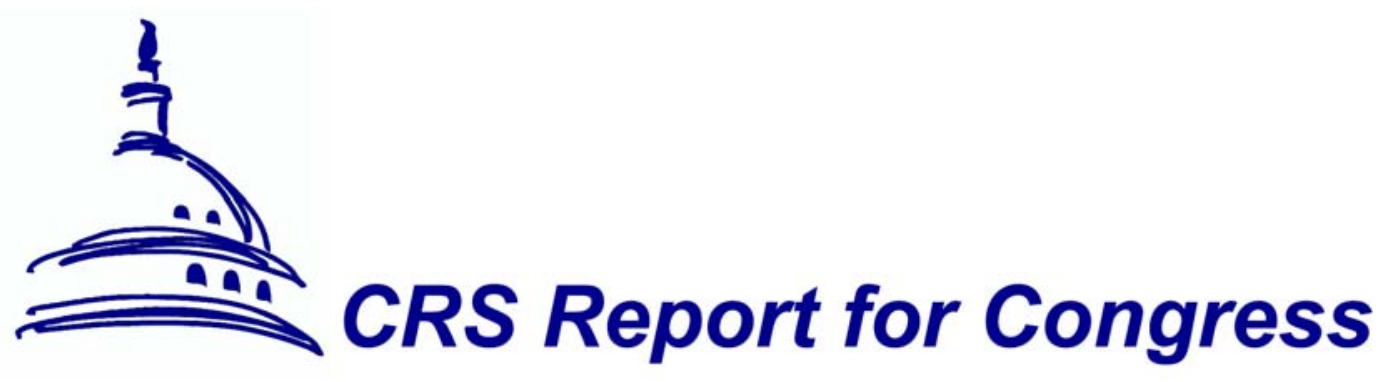

\title{
Iceland's Financial Crisis
}

\author{
James K. Jackson \\ Specialist in International Trade and Finance \\ Foreign Affairs, Defense, and Trade Division
}

\section{Summary}

On November 19, 2008, Iceland and the International Monetary Fund (IMF) finalized an agreement on a $\$ 6$ billion economic stabilization program supported by a $\$ 2.1$ billion loan from the IMF. Following the IMF decision, Denmark, Finland, Norway, and Sweden agreed to provide an additional $\$ 2.5$ billion. Iceland's banking system had collapsed as a culmination of a series of decisions the banks made that left them highly exposed to disruptions in financial markets. The collapse of the banks also raises questions for U.S. leaders and others about supervising banks that operate across national borders, especially as it becomes increasingly difficult to distinguish the limits of domestic financial markets. Such supervision is important for banks that are headquartered in small economies, but operate across national borders. If such banks become so overexposed in foreign markets that a financial disruption threatens the solvency of the banks, the collapse of the banks can overwhelm domestic credit markets and outstrip the ability of the central bank to serve as the lender of last resort. This report will be updated as warranted by events.

\section{Background}

Iceland $^{1}$ is the smallest economy within the Organization for Economic Cooperation and Development (OECD) with a gross domestic product (GDP) in 2007 of about $\$ 11.8$ billion, as indicated in Table 1. Historically, Iceland's economy has been based on marine and energy resources. More recently, Iceland has developed a strong services sector, which accounts for two-thirds of the economic output. Since 2000, Iceland has experienced particularly strong growth in its financial services sector. Trade accounts for a large share of Iceland's GDP, with imports and exports of goods and services equivalent in value to $46 \%$ and $35 \%$, respectively, of GDP. Fish and other marine products were Iceland's main export item until 2006, when Iceland began to capitalize on its abundant thermal energy resources to produce and export aluminum. As the data in Table 1 indicate, Iceland is expected to experience a slowdown in its rate of economic growth in

1 This report relies heavily on: The Economy of Iceland, The Central Bank of Iceland, August 2008. 
2008 and is projected by the International Monetary Fund to experience a negative rate of growth in 2009. Iceland also has battled a high and rising rate of inflation, as measured by the consumer price index (CPI) and interest rates, as measured by the long-term government bond rates.

\section{Table 1. Iceland: Main Economic Indicators and Projections (in billions of dollars and in percent)}

\begin{tabular}{lrrrrrr}
\hline & $\mathbf{2 0 0 4}$ & $\mathbf{2 0 0 5}$ & $\mathbf{2 0 0 6}$ & $\mathbf{2 0 0 7}$ & $\mathbf{2 0 0 8}$ & $\mathbf{2 0 0 9}$ \\
\hline & \multicolumn{3}{c}{ Actual } & \multicolumn{3}{c}{ Projected } \\
\hline GDP (in \$billions) & $\$ 9.9$ & $\$ 10.6$ & $\$ 11.1$ & $\$ 11.8$ & NA & NA \\
Real GDP growth & $7.7 \%$ & $7.4 \%$ & $4.4 \%$ & $4.9 \%$ & $0.3 \%$ & $-3.1 \%$ \\
CPI & $3.2 \%$ & $4.0 \%$ & $6.8 \%$ & $5.0 \%$ & $12.1 \%$ & $11.2 \%$ \\
Interest rates & $7.5 \%$ & $7.7 \%$ & $9.3 \%$ & $9.8 \%$ & $11.4 \%$ & $10.3 \%$
\end{tabular}

Source: World Economic Outlook, October 2008, International Monetary Fund; and Economic Outlook, Preliminary Edition, June 2008, Organization for Economic Cooperation and Development.

\section{Recent Economic Activity}

A combination of economic factors over the early to mid-2000s led to Iceland's current economic and banking distress. In particular, access to easy credit, a boom in domestic construction that fueled rapid economic growth, and a broad deregulation of Iceland's financial sector spurred the banks to expand rapidly abroad and eventually played a role in the eventual financial collapse. Iceland benefitted from favorable global financial conditions that reduced the cost of credit and a sweeping liberalization of its domestic financial sector that spurred rapid growth and encouraged Iceland's banks to spread quickly throughout Europe.

In 2004, Iceland's commercial banks increased their activity in the country's mortgage market by competing directly with the state-run Housing Financing Fund (HFF), which had been the major provider of mortgage loans. In contrast to the Housing Financing Fund, the commercial banks began offering loans with lower interest rates, longer maturities, and a higher loan to value ratio. Also, the banks did not require a real estate purchase as a precondition for a loan, which made it possible for homeowners to refinance existing mortgages and to access the equity in their homes for consumption or investment purposes. These measures spurred an expansion in credit and caused real estate prices to soar. In addition, the improving economic conditions led to an expansion in consumer spending which resulted in rising inflation and a larger trade deficit. As a further stimulus to the economy, the Icelandic government reduced both direct and indirect taxes, which provided further impetus to consumer spending.

By 2004, Iceland's central bank began tightening monetary policy by raising interest rates in an attempt to curtail inflationary pressures. Between 2004 and 2007, the Bank raised nominal short-term interest rates from 5\% to $15 \%$. The increase in interest rates, however, was not reflected in the interest rates the Housing Financing Fund charged for mortgages. As a result, the comparatively low interest rates charged by the HFF pushed up demand for housing which, in turn, further inflated the price of homes in Iceland. In addition, since the commercial banks were willing to make loans based on the 
equity in a home, the rising equity values in housing allowed consumers to finance a higher level of consumption, with the attendant pressure on inflation and interest rates. At the same time, the higher domestic interest rates made bond issues in krona attractive to foreign investors who could borrow abroad at low interest rates, which placed upward pressure on the value of the krona and worsened the trade deficit.

As Iceland deregulated its commercial banks, those banks expanded to the United Kingdom, the United States, Scandinavia, continental Europe, and elsewhere. Iceland has five commercial banks: Glitnir, Kaupthing, Nyi Landsbanki, Straumur Investment Bank, and Icebank, which serves as the clearing house for the 20 locally-run savings banks. The three largest banks, Kaupthing, Landsbanki, and Glitnir, have total assets of more than $\$ 168$ billion, or 14 times Iceland's GDP. Iceland also has 20 savings banks, with assets at the end of 2007 valued at $\$ 9$ billion.

After Iceland deregulated its commercial banks, the banks expanded their operations abroad by acquiring subsidiaries in commercial banking and in securities brokerages. At the end of 2007, almost half of the total assets of the largest commercial banking groups were accounted for by foreign subsidiaries, most of them located in Northern Europe, and in 2007 about $58 \%$ of their overall income was generated from their subsidiaries located abroad. By the end of 2007, Iceland's three largest banks relied on short-term financing for $75 \%$ of their funds, mostly through borrowing in the money markets and in the short-term interbank market. Iceland's banks are a hybrid between commercial and investment banks, with relatively large exposure to market risk. By March 2008, investors had become wary of Iceland's banks due to their large funding needs and high dependence on short-term funds in money markets. Even before the financial crisis erupted in fall 2008, the Central Bank of Iceland and other institutions forecasted a slowdown or a contraction in Iceland's rate of economic growth in 2008 and 2009.

\section{Banking Collapse}

Between October 7 and 9, 2008, Iceland's Financial Supervisory Authority (FSA), an independent state authority with responsibilities to regulate and supervise Iceland's credit, insurance, securities, and pension markets, took control of, without actually nationalizing them, three of Iceland's largest banks: Landsbanki, Glitnir Banki, and Kaupthing Bank. The takeover occurred prior to a scheduled vote by shareholders to accept a government plan to purchase the shares of the banks in order to head off the collapse of the banks. At the same time, Iceland suspended trading on its stock exchange for two days. ${ }^{2}$

The takeover of the banks was orchestrated in an attempt to quell a sharp depreciation in the exchange value of the Icelandic krona. The krona depreciated relative to the euro and the dollar between January 2008 and July 2008; the depreciation became more pronounced after July 2008. For Iceland, which relies heavily on trade, a sharp depreciation in its currency increases the costs of its imports and adds to domestic inflationary pressures.

${ }^{2}$ Wardell, Jane, Iceland's Financial Crisis Escalates, BusinessWeek, October 9, 2008; Pfanner, Eric, Meltdown of Iceland's Financial System Quickens, The New York Times, October 9, 2008. 


\section{CRS-4}

The demise of Iceland's three largest banks is attributed to an array of events, but primarily stems from decisions by the banks themselves. Some observers argued that the collapse of Lehman Brothers set in motion the events that finally led to the collapse of the banks, ${ }^{3}$ but this conclusion is controversial. Some have argued that at the heart of Iceland's banking crisis is a flawed banking model that is based on an internationally active banking sector that is large relative to the size of the home country's GDP and to the fiscal capacity of the central bank. ${ }^{4}$ As a result, a disruption in liquidity threatens the viability of the banks and overwhelms the ability of the central bank to act as the lender of last resort, which undermines the solvency of the banking system.

By the time of the acknowledged start of the global financial crisis in mid-2007, Iceland's central bank and Iceland's banks themselves had begun to recognize the vulnerability of the banks. In particular, officials in Iceland as well as financial observers in Europe had begun to reassess the risks associated with various financial instruments, and to raise questions about the asset strength of the banks and the asset size of the banks relative to the size of Iceland's economy. In addition, by late 2007, various organizations had begun to recognize the imbalances that were becoming apparent in Iceland's economy and had forecast a slowdown in Iceland's torrid pace of economic growth for 2008 and 2009. ${ }^{5}$

When Lehman Brothers collapsed, the international financial markets had already begun to reassess the risks associated with a broad range of financial instruments. Eventually, this reassessment of risks undermined the remaining amount of trust that existed in the credit markets, which caused banks and other financial firms to grow unwilling to make loans to short-term money markets and to engage in interbank lending, which caused those activities to freeze up. For Iceland's three largest banks, this collapse in short-term borrowing meant that they found that it was increasingly difficult to finance debts in the interbank market.

In addition, Iceland's Landsbanki and Kaupthing Bank experienced a sharp rise in the cost of private deposit insurance. This withdrawal of credit eliminated a major source of the bank's funding and threatened their ability to finance the nation's trade deficits. Typically, this situation is remedied by the central bank, which stands as the bank of last resort. In Iceland's case, however, the debts of the commercial banks were so large that Iceland's central bank was unable to guarantee the banks' loans, which lead to the collapse of the banks. In turn, the krona experienced a serious depreciation in its value, which raised the cost of imports and threatened to fuel domestic inflation. The large foreign debts held by Iceland's banks proved to be unsupportable once they could not utilize the interbank market to refinance their substantial loans.

The FSA transferred part of the three banks' operations to new bank entities that it formed and that are fully owned by the Icelandic Government. As part of these actions,

${ }^{3}$ Portes, Richard, The Shocking Errors Behind Iceland's Meltdown, Financial Times, October 13, 2008, p. 15.

${ }^{4}$ Buiter, Willem H., and Anne Sibert, The Icelandic Banking Crisis and What to Do About it: The Lender of Last Resort Theory of Optimal Currency Areas. Policy Insight No. 26, Centre for Economic Policy Research, October 2008. p. 2.

5 The Economy of Iceland, p. 9-11. 
the FSA dismissed the members of the boards of directors and appointed individuals to serve on a Receivership Committee. The respective committees assumed supervision of the assets and operations of the newly-formed banks. During the same two-day period, Iceland's central bank abandoned its attempt to maintain the value of the krona. With the take-over of the three major banks, the central bank effectively shut down the last clearing houses for trading krona.

On October 15, 2008, the Central Bank of Iceland set up a temporary system of daily currency auction to facilitate international trade. Without a viable currency, there was no way to support the banks, which have done the bulk of their business in foreign markets. The financial crisis also created problems with Great Britain, because hundreds of thousands of Britons hold accounts in online branches of the Icelandic banks and fear those accounts will all default. The government of British Prime Minister Gordon Brown has used powers granted under anti-terrorism laws to freeze British assets of Landsbanki until the standoff is resolved.

On November 19, 2008, Iceland and the International Monetary Fund (IMF) finalized an agreement on an economic stabilization program supported by a $\$ 2.1$ billion two-year standby arrangement from the IMF. ${ }^{6}$ Upon approval of the IMF's Executive board, the IMF released $\$ 827$ million immediately to Iceland with the remainder to be paid in eight equal installments, subject to quarterly reviews. As part of the agreement, Iceland has proposed a plan to restore confidence in its banking system, to stabilize the exchange rate, and to improve the nation's fiscal position. Also, as part of the plan, Iceland's central bank raised its key interest rate by six percentage points to $18 \%$ on October 29, 2008 to attract foreign investors and to shore up its sagging currency. ${ }^{7}$ The IMF's Executive Board had postponed its decision on a loan to Iceland three times, reportedly to give IMF officials more time to confirm loans made by other nations. Other observers argued, however, that the delay reflected objections by British, Dutch, and German officials over the disposition of deposit accounts operated by Icelandic banks in their countries. Iceland reportedly smoothed the way by agreeing in principle to cover the deposits, although the details had not be finalized. In a joint statement, Germany, Britain, and the Netherlands said on November 20, 2008 that they would "work constructively in the continuing discussions" to reach an agreement. ${ }^{8}$ Following the decision of IMF's Executive Board, Denmark, Finland, Norway, and Sweden agreed to provide an additional $\$ 2.5$ billion in loans to Iceland.

\section{Conclusions}

The failure of Iceland's banks raises questions about bank supervision and crisis management for governments in Europe and the United States. This incident raises questions about how national governments should address the issue of supervising foreign financial firms that are operating within their borders and how to protect their depositors

${ }^{6}$ Anderson, Camilla, Iceland Gets Help to Recover From Historic Crisis, IMF Survey Magazine, November 19, 2008.

7 Iceland Raises Key Rate by 6 Percentage Points, The New York Times, October 29, 2008.

8 Jolly, David, Nordic Countries Add \$2.5 Billion to Iceland's Bailout, The New York Times, November 20, 2008. 
when a foreign-owned firm may attempt to withdraw deposits from one market in order to offset losses in another. One approach focuses on broad levels of cooperation between national governments with each government addressing the crisis from its own perspective and in its own limited way. For a number of governments in Europe this approach is appealing, because their economies and their banks have felt little direct effect from the crisis.

An alternative approach argues in favor of a more integrated and coordinated response from national governments and central banks. Proponents of this approach argue that a coordinated systemic approach is necessary, because financial markets in the United States and Europe have become highly integrated as a result of cross-border investment by banks, securities brokers, and other financial firms. As a result of this integration, economic and financial developments that affect national economies are difficult to contain and are quickly transmitted across national borders, as attested to by the financial crisis of 2008. As financial firms react to a financial crisis in one area, their actions can spill over to other areas as they withdraw assets from foreign markets to shore up their domestic operations. For instance, as Icelandic banks began to default, Britain used an anti-terrorism law to seize the deposits of the banks to prevent the banks from shifting funds from Britain to Iceland. ${ }^{9}$ Banks and financial firms in Europe have felt the repercussions of the U.S. financial crisis as bank balance sheets have deteriorated and as U.S. firms and European firms have adjusted their operations in response to the crisis.

The Icelandic case also raises questions about the cost and benefits of branch banking across national borders where banks can grow to be so large that disruptions in the financial market can cause defaults that outstrip the resources of national central banks to address. Such branch banking across national borders has significantly expanded financial opportunities for individual investors and firms alike and is unlikely to disappear as a result of the current financial crisis. Nevertheless, if some financial institutions are deemed to be too big to fail, financial regulators and national governments may be called on to address the issue of how such institutions should be supervised when their operations span national borders and they are engaged in a vast array of banking and investment operations.

9 Benoit, Bertrand, Tom Braithwaaite, Jimmy Burns, Jean Eaglesham, et. al., Iceland and UK clash on Crisis, Financial Times, October 10, 2008, p. 1. 